\title{
The transformation of Caribbean coral communities since humans
}

\author{
Katie Cramer ${ }^{1}$, Mary Donovan ${ }^{2}$, Jeremy Jackson ${ }^{3}$, Benjamin Greenstein ${ }^{4}$, Chelsea \\ Korpanty $^{5}$, Geoffrey Cook $^{6}$, and John Pandolfi ${ }^{7}$ \\ ${ }^{1}$ Arizona State University \\ ${ }^{2}$ University of California Santa Barbara \\ ${ }^{3}$ American Museum of Natural History \\ ${ }^{4}$ Roger Williams University \\ ${ }^{5}$ MARUM \\ ${ }^{6}$ New England College \\ ${ }^{7}$ The University of Queensland
}

January 12, 2021

\begin{abstract}
The mass die-off of Caribbean corals has transformed many of this region's reefs to macroalgal-dominated habitats since systematic monitoring began in the 1970s. Although attributed to a combination of local and global human stressors, the lack of long-term data on Caribbean reef coral communities has prevented a clear understanding of the causes and consequences of coral declines. We integrated paleoecological, historical, and modern survey data to track the prevalence of major coral species and life history groups throughout the Caribbean from the pre-human period to present. The regional loss of Acropora corals beginning by the 1960s from local human disturbances resulted in increases in the prevalence of formerly subdominant stress-tolerant and weedy scleractinian corals and the competitive hydrozoan Millepora beginning in the 1970s and 1980s. These transformations have resulted in the homogenization of coral communities within individual countries. However, increases in stress-tolerant and weedy corals have slowed or reversed since the 1980s and 1990s in tandem with intensified coral bleaching. These patterns reveal the long history of increasingly stressful environmental conditions on Caribbean reefs that began with widespread local human disturbances and have recently culminated in the combined effects of local and global change.
\end{abstract}

The transformation of Caribbean coral communities since humans

Katie L Cramer, Mary K Donovan, Jeremy BC Jackson, Benjamin J Greenstein, Chelsea A Korpanty, Geoffrey M Cook, John M Pandolfi

The mass die-off of Caribbean corals has transformed many of this region's reefs to macroalgal-dominated habitats since systematic monitoring began in the 1970s. Although attributed to a combination of local and global human stressors, the lack of long-term data on Caribbean reef coral communities has prevented a clear understanding of the causes and consequences of coral declines. We integrated paleoecological, historical, and modern survey data to track the prevalence of major coral species and life history groups throughout the Caribbean from the pre-human period to present. The regional loss of Acropora corals beginning by the 1960s from local human disturbances resulted in increases in the prevalence of formerly subdominant stresstolerant and weedy scleractinian corals and the competitive hydrozoan Millepora beginning in the 1970s and 1980s. These transformations have resulted in the homogenization of coral communities within individual countries. However, increases in stress-tolerant and weedy corals have slowed or reversed since the 1980s and 1990s in tandem with intensified coral bleaching. These patterns reveal the long history of increasingly stressful environmental conditions on Caribbean reefs that began with widespread local human disturbances and have recently culminated in the combined effects of local and global change. 
Keywords : coral reefs, climate change, fishing, runoff, conservation paleobiology, historical ecology

\section{Introduction}

Living cover of reef-building corals has declined on Caribbean reefs by 50 to 80 percent since systematic monitoring began in the late 1970s [1,2] with many reefs transformed from coral- to algal-dominated habitats $[2,3]$. Coral declines have been attributed to multiple anthropogenic stressors including fishing, land-based pollution, and global warming as well as epizootics afflicting corals and urchins [2-4]. The mass mortality of the long-spined sea urchinDiadema antillarum in the early 1980s removed the last abundant herbivore from reefs that were largely devoid of herbivorous fish after decades to centuries of overfishing [5-8], precipitating an explosion of macroalgae on reefs across the Caribbean [2]. Outbreaks of "White Band Disease" appeared on many reefs around this same time, eventually killing over $80 \%$ of elkhorn coral Acropora palmatawhich previously dominated reef crest zones and staghorn coralAcropora cervicornis which previously dominated midslope zones [9-11]. These events were followed by regional coral bleaching in the 1990s, leading to further increases in coral diseases and in some instances a further replacement of corals by macroalgae [12]. These factors acted synergistically to rapidly transform coral communities. A recent Caribbean-wide analysis of Acropora presence and dominance from the pre-human period to the present revealed that the loss of these corals initially began in the 1950s and 1960s, decades before the first recorded observations of coral disease and bleaching [13].

While the long-term decline of Caribbean acroporid corals has been documented on a regional scale [13], the effects of Acroporaloss on Caribbean reef coral community composition and ecosystem functioning are unknown. Although isolated surveys of altered reefs have found an increase in the relative abundance of low-relief "weedy" species such as Porites and Agaricia over the past few decades [14-17], the magnitude and geographic extent of community change are unresolved. Assessing long-term change in the full reefbuilding coral community will shed light on the ecological causes and consequences of recent coral declines and assist in guiding appropriate management interventions. We compiled an extensive dataset on the prevalence of common hermatypic coral species and genera at thousands of individual reef sites across the Caribbean spanning the Late Pleistocene epoch ( $\sim 131,000 \mathrm{ybp})$ - when humans were absent from the Americas - up to 2011. By pinpointing the initial timing of major community transformations, we inferred general anthropogenic causes of change (i.e., local human stressors and/or climate change). To provide additional insight into the ecological context of change, we also tracked change in (a) major coral ecological guilds based on various life history traits and (b) inter-site community heterogeneity.

\section{Methods}

\section{Coral community composition database}

Data on coral species composition from the pre-human period to the present were compiled from semiquantitative, quantitative, and qualitative records from the primary peer-reviewed scientific literature, government reports, and historical literature. These data were collected via surveys of uplifted fossil reefs, analysis of coral fossils in reef matrix cores, qualitative field notes from boat-based or snorkel surveys, high-resolution aerial photographs, and underwater field surveys using SCUBA. Most of the coral species composition data since the 1980s were received directly from contributors or gleaned from peer-reviewed literature to construct the Global Coral Reef Monitoring Network (GCRMN) database that assessed trends in Caribbean reef benthic communities from 1970-2011 (Table S1; ref 2).

Temporal changes were tracked for 14 common coral taxonomic groups that were consistently recorded within each time bin (henceforth termed "species groups": Acropora cervicornis , Acropora palmata , Agaricia spp., Montastraea cavernosa ,Colpophyllia spp., Diploria spp., Madracis spp.,Meandrina spp., Millepora spp., Orbicella spp., branching Porites spp., Porites astreoides ,Siderastrea spp., and Stephanocoenia spp.). To provide sufficient temporal resolution and ensure adequate sample sizes for assessing change over the full time series, data were grouped into eleven time bins: Late Pleistocene $(\sim 131,000-12,000$ years ago, which we also refer to as the pre-human period), Holocene ( $~ 9,100$ years ago-1500 AD), 1500-1959, 1960-1969, 19701979, 1980-1984, 1985-1989, 1990-1994, 1995-2000, 2001-2004, and 2005-2011. Bins were reduced to 5-year 
increments after 1980 (except for a six-year increment for the most recent bin) due to the large increase in reef survey effort following the mass die-off of the urchinDiadema antillarum. The pre-human bin encompasses a period of high-magnitude fluctuations in sea level and climate (during whichAcropora coral dominance persisted in the Caribbean; ref 18), whereas the pre-historic bin encompasses a period with relatively higher stability in climate and sea level [19].

Data were extracted from text, tables and figures, and maps. Qualitative data were included in the database if, in addition to presence/absence information for at least one coral species, the following information was also available: (1) age of fossil data or year of observation of modern data, (2) original source of data, (3) country and island, coastline, or reef site, and (4) water depth or reef zone. Data were recorded at the survey level, with a survey constituting a unique combination of reef site, depth zone, and year. For surveys which included multiple replicates (i.e., transects or quadrats) at the same site, depth zone, and year/period, an overall value was computed for all replicates. Surveys constituted individual reef "sites" and in some cases encompassed more extensive areas such as entire reef tracts, bays, or banks.

We analyzed data from "reef crest" and "midslope" reef zones separately. Generally, the reef crest data spanned 0-6m water depth and midslope data spanned between $6-20 \mathrm{~m}$, as $6 \mathrm{~m}$ was the depth at which dominance typically transitioned from A. palmata to A. cervicornisin the semi-quantitative and quantitative data. However, the reef crest/midslope zone delineation was made on a location-by-location basis by first considering water depth and, when available, additional environmental characteristics such as wave exposure and reef morphology. For some offshore locations with presumably higher water clarity, the cutoff was closer to $10 \mathrm{~m}$. When a precise water depth was not available, we utilized Acropora species presence and/or dominance in addition to environmental characteristics to delineate between zones [13]. When not reported in the papers from which data were extracted, paleo water depths were determined using the procedure outlined in ref. 13. Surveys from backreef habitats, reef flats, and reef pavements were excluded from our database, as these reef zones are not the preferred environments for Caribbean Acropora [20].

Change in coral community composition was assessed using coral species presence/absence data, extracted from species rankings, presence/absence, percent living coral cover, number of individual colonies, and percent weight or volume of coral fossils. Only species included in the 14 commonly occurring species groups were considered in our analyses. Data recorded as "Porites spp." were assumed to be branching Porites spp. (whereas records listing "Porites astreoides" were assigned to a separate category) and data recorded as "Montastraea spp." were assumed to beOrbicella spp. because species within these complexes are difficult to distinguish and were not recognized as separate species until 1992 [21]. Pseudodiploria clivosa , Pseudodiploria strigosa, and Diploria labyrinthiformis were assigned toPseudodiploria spp., as these species were placed within the same genus until 2012 [22].

\section{Coral life history strategies}

To infer potential environmental changes driving coral community shifts, we also tracked trends in coral life history groups. We adapted a trait-based classification approach that grouped scleractinians into four life history strategies influenced primarily by colony morphology, growth rate, and reproductive mode [23]. This configuration roughly follows Grime's arrangement of plant species into three basic life history strategies: competitive species that maximize growth, stress tolerant species that maximize survival, and ruderal or weedy species that maximize fecundity [24-25]. A fourth category, generalist species, represents a mixture of these strategies. However, because the generalist group was composed primarily of corals that are sub-dominant in the Caribbean, this group was not included in our analyses. To add ecological context to these groupings, we collated from the literature taxon-specific, qualitative measures of additional life history characteristics including sexual reproductive output (larval recruitment), asexual propagation via colony fragmentation, interspecific aggression, and susceptibility to disturbances such as sedimentation and bleaching (Tables 1,S2). Although larval recruitment represents the end-point of fecundity, fertilization, dispersal, and early post-settlement mortality and is not a life history characteristic per se, this metric is closely linked to life history strategy [26] and provided valuable ecological context for observed community change. Our life history groupings closely followed those determined by refs 23 and 27 , with two exceptions described 
below.

The competitive life history group included Acropora cervicornis, A. palmata, and the hydrozoan Millepora $s p p$. This group is distinguished by fast growth rates, large branching morphologies that can outcompete other corals for light and/or space, medium to high levels of aggression, a spawning mode of reproduction but low rates of sexual recruitment, high propensity for asexual reproduction via fragmentation, and low tolerance to disturbances such as sedimentation and thermal stress (Tables S2,S3). This combination of traits historically allowed Acropora corals to dominate shallow, high energy reef environments prior to local and global anthropogenic stressors [28-30]. Although not included in the previous analyses of coral life history guilds, we included Millepora in the competitive category because of its Acropora -like ability to preempt space on reefs due primarily to fragmentation and fast growth and its high susceptibility to bleaching (Tables $1, \mathrm{~S} 2$, refs $31-32)$.

The stress-tolerant life history group includes Colpophyllia natans, Diploria spp., Meandrina spp., Montastrea cavernosa, Orbicella spp., Siderastrea spp., andStephanocoenia spp. This group is distinguished by slow to moderate growth rates, large and domed morphologies with higher ability to clear sediment and other particles and resistant to storm damage, a spawning mode of reproduction with low to moderate sexual recruitment, low to high interspecific aggression, and relatively higher tolerance for sedimentation and thermal stress (Tables 1,S2). Although some stress-tolerant corals have a higher susceptibility to bleaching, colony survival rates are typically high within this group [33]. This combination of traits historically allowed these species to persist and dominate in environments subject to frequent, low-magnitude disturbances such as sediment resuspension and temperature stress [30,34-35]. Because the three extant Orbicella species were until recently classified as Montastrea annularis [21], we assigned Orbicella spp. to the stress-tolerant category in accordance with the classification for M. annularis [23]. However, this genera's historical dominance on midslope zones on many Caribbean reefs and its high levels of interspecific aggression via mesenterial filaments [36] suggest it may also be considered as a highly competitive taxon. Therefore, we ran two sets of analyses of trends in coral life history and species prevalence: one that included Orbicella in the stress-tolerant group and one that included Orbicella in the competitive group.

The weedy life history group includes Agaricia spp., Madracis spp., branching Porites spp., and P. astreoides . This group is distinguished by lower-relief plating, foliose, branching, and domed morphologies with slow to fast growth rates, a brooding mode of reproduction that allows for rapid colonization at low population densities, generally high rates of sexual recruitment, high to low occurrence of asexual reproduction via fragmentation, low interspecific aggression, generally high susceptibility to bleaching, and high tolerance of sedimentation (Tables 1,S2). This combination of traits historically allowed these early-successional species to opportunistically and rapidly colonize open spaces cleared by high-magnitude acute disturbances $[28,37$ $38)$.

\section{Analyses of coral community change}

To estimate the proportion of reef sites containing each coral life history and species group in each time interval, we utilized binomial generalized linear mixed effects models that predicted the proportion of sites containing each life history group as a function of time bin, coral species group, and their interaction as fixed effects and country as a random effect. The interaction term was included to allow for varying temporal trends across individual taxonomic and functional groups. The random effect of country was included to account for uneven geographic sampling across time bins. To ensure equal numbers of surveys were included for each species group within a life history group, only surveys with presence/absence values for the entire complement of coral species within a given life history group were included in each model. Models were fitted using the 'glmer' function in the R package 'lme4'. Mean fitted values and $95 \%$ confidence intervals of the proportion of sites with a coral life history group and its constituent species groups were plotted for each time bin using the 'plot_model' function in the R package 'sjPlot'. Significant changes in mean fitted values relative to the Pleistocene baseline and subsequent peak values were assessed via a Tukey post-hoc test using the 'emmeans' function in the $\mathrm{R}$ package 'emmeans'. 
To assess the effects of coral community change on regional diversity patterns, we tracked temporal changes in community dissimilarity. We utilized species presence/absence matrices to compute Jaccard's dissimilarity index [39]. To account for the higher number of reef sites and countries added in the latter part of the time series, we restricted our analysis to change in coral community dissimilarity within individual countries only. Within each time bin, the dissimilarity was computed between all possible combinations of reef sites located within the same country. For each country and time bin combination, a mean dissimilarity value was computed. To equalize the influence of each country and to avoid giving undue influence to countries with a larger number of surveys, mean dissimilarity values were computed for each country prior to computing the overall mean for a time bin. Uncertainty estimates were obtained via a bootstrap procedure that sampled with replacement from the distribution of mean within-country dissimilarity values for each time bin $n$ times (with $n=$ number of countries for that bin). This resampling procedure was performed 1000 times for each time bin; $95 \%$ confidence intervals were determined from the $5^{\text {th }}$ and $95^{\text {th }}$ quantiles of the resampled distributions. Significant differences in mean within-country coral community dissimilarity values were determined by pairwise comparisons performed via permutation tests (with 1000 iterations) using the 'pairwise.perm.t.test' function in the 'RVAideMemoire'package in R. All statistical analyses were performed using the program Rv3.4 [40], and all P-value corrections for multiple testing were computed using the method outlined in ref 41.

\section{Results}

Species community database

Coral species presence and absence data were compiled from 2396 reef sites from 26 countries for the reef crest zone and 5091 reef sites from 30 countries for the midslope zone (Figure 1). Full community data (containing a 0 or 1 value for all 14 common coral species groups) were available for all time periods and were compiled from 1569 reef sites from 24 countries for the reef crest and 3207 sites from 27 countries for the midslope zone (Tables S3,S4).

\section{Long-term change in coral community composition}

Since the mid- $20^{\text {th }}$ century, shallow water reefs across the Caribbean have transformed from systems dominated by competitive corals to systems dominated by stress-tolerant and weedy corals (Figures 2, 3). At both the reef crest and midslope zones, coral community change occurred via three stages: (1) significant declines in competitive corals relative to the pre-human baseline occurring by the 1960s; (2) significant increases in stress-tolerant and weedy corals occurring by the 1970s and 1980s; and (3) significant declines or leveling-off of stress-tolerant and weedy corals since the 1980s or 1990s (Table 2, Figures 2, 3). These trends were consistent whether Millepora was included or excluded from the competitive life history group and whether Orbicella was included in the competitive or stress-tolerant group, with the exception that the inclusion of both Orbicellaand Millepora in the competitive group rendered overall declines in competitive corals non-significant at the reef crest zone (Figures S1,S2, Table S5). For competitive corals in both zones and stress-tolerant and weedy corals in the midslope zone, the first significant change relative to the prehuman baseline occurred in the Holocene, reflecting contrasting environmental conditions and/or data types between the Pleistocene and Holocene (Figures 2,3).

The assessment of trends for individual species groups revealed that at both reef zones, the prevalence of competitive Acropora palmataand A. cervicornis declined significantly between the Pleistocene and Holocene periods. After the Holocene, the next significant decline in competitive Acropora corals occurred in the 1960s; the prevalence of these corals remained significantly lower than pre-human levels from this point forward (Table 2, Figures 2a, 3a). In contrast, prevalence of the competitive hydrozoan Millepora increased significantly across the full time series, peaking in the late 1990s (crest) or early 2000s (midslope). At the reef crest zone,Siderastrea was the only stress-tolerant taxon that increased significantly from the prehuman period to present, while at the midslope zone all stress-tolerant taxa except for Diploria and Orbicella increased significantly across the full time series (Table 2, Figures 2b,3b). The post-1980s declines in the prevalence of stress-tolerant corals that occurred at the reef crest zone were driven by declines in Colpophyllia, 
Diploria, Montastrea cavernosa, and Siderastrea while post-1990s leveling off in the prevalence of this group at the midslope zone was driven by declining or consistent prevalence of Colpophyllia, Diploria, andMontastrea cavernosa. At both reef zones, all weedy taxa increased significantly across the full time series with the exception of Madracis in the reef crest (Table 2, Figures 2c,3c). Initial significant increases in individual weedy coral species primarily occurred in the 1980s (crest) and in the 1970s (midslope). Significant post-1980s declines in the weedy group at the reef crest reflect contemporaneous declines in Agaricia , branching Porites, and P. astreoides, while significant post-1990s declines in the weedy group at the midslope reflect declines in Agaricia and branching Porites .

\section{Community dissimilarity}

Within-country community dissimilarity declined significantly from the historic period to present at both reef zones; the decline was more striking in the latter (Fig 4). Because the Pleistocene and Holocene communities at both reef zones were more variable and had notably lower average dissimilarity values compared to subsequent periods - likely due to time averaging of the fossil data which comprise these time bins - we designated the historical time bin (1500-1959) as the baseline for this community metric. At both the reef crest and midslope zones, pairwise comparisons of mean within-country dissimilarity values showed significant declines from the baseline historical period (1500-1959) to most recent period (2005-2011), with the first significant decline relative to the baseline occurring in 2000-2004 at the reef crest and in 1985-1989 at the midslope zones (Figure 4).

\section{Discussion}

\section{The transformation of coral communities from pre-human period to present}

Our 131,000-year record of coral community composition reveals that since humans arrived in the Caribbean, coral reefs throughout this region have transformed from systems dominated by competitiveAcropora corals typified by fast growth, large and structurally complex colonies, and high rates of reproduction via fragmentation and lower tolerance to human disturbances to systems dominated by stress-tolerant and weedy corals with relatively slower growth, lower-relief colony forms, and higher tolerance to human disturbances (Figures 2,3). Initial significant declines in Acropora occurred by the 1960s, a decade before the first recorded instances of White Band Disease and two decades before the die-off of the Diadema urchin and widespread coral bleaching. These early Acropora declines were related to local human stressors but not regional stressors including climate change [13], although more recent outbreaks of White Band Disease since the 1990s have been linked to climate change [42]. The initial mid-20 ${ }^{\text {th }}$ century loss of Acropora was followed by a lagged increase in the prevalence of stress-tolerant and weedy corals that began in the 1970s and 1980s. By 2005-2011, these community shifts culminated in previously subdominant stress-tolerant and weedy coral taxa being present at 2-3 times more sites than Acropora, the genus which had continuously dominated shallow reef zones across the Caribbean throughout the Pleistocene and Holocene up until the mid- $20^{\text {th }}$ century $[13,18,29]$. The loss of Acropora also appears to have facilitated an increase in the prevalence of Millepora, a non-framework building hydrozoan with a competitive life history strategy (Figures 2a,3a).

Although initial declines in Acropora predate regional disturbances, subsequent changes bear a clear imprint of anthropogenic climate change. For instance, while the prevalence of stress-tolerant and weedy corals is significantly higher today than the pre-human period, increases generally leveled off or reversed beginning in the late 1980s. The slowdown of increases in these corals is likely a response to the rapid explosion in benthic macroalgae following the die-off of the keystone herbivore Diadema antillarum and increases in bleachingrelated mortality from anthropogenic temperature stress. The more marked declines in Agarcia compared toPorites likely reflect the greater sensitivity of Agariciato thermal stress: Agaricia experienced widespread bleaching episodes during thermal anomalies in the 1980s and 1990s [43-45]. The post-1980s declines/plateaus in stress-tolerant and weedy species shown in this study are also a reflection of the increasingly frequent epizootics affecting these corals over the past 2-3 decades and that are linked to a combination of local and global anthropogenic stressors [46].

Our time series suggests that the Caribbean-wide loss of Acroporacorals opened up both physical substrate 
and niche space for formerly subdominant corals with stress-tolerant and weedy life history strategies to occupy. The uniform rarity of Acropora and consistently high prevalence of weedy and stress-tolerant species (particularly Siderastrea, Agaricia, and Porites ) have greatly reduced the distinctiveness of modern coral communities at larger geographic scales, resulting in a Caribbean-wide homogenization beginning in the 1960s at the midslope zone and in the 1980s at the reef crest zone (Figures 2-4). The homogenization of reef coral communities following the loss of Acropora and Orbicella has been reported for the Florida reef tract [47] and Belize and Panama [15]. However, our study shows that coral communities have become more homogeneous across the entirety of the Caribbean. Although overall community distinctiveness has declined since the baseline historical period (1500-1959), this trend leveled off by the 1990s as increases in the prevalence of stress-tolerant and weedy corals were halted following climate change-related bleaching and disease (Fig 4).

Although broadly similar compositional changes occurred in coral communities at the reef crest and midslope zones, subtle distinctions in the trajectories of change between zones provide insight into their varying susceptibilities to different stressors. Declines in community dissimilarity were more striking at the midslope, reflecting the more precipitous decline of $A$. cervicornis at this zone compared to the decline of $A$. palmata at the reef crest (Figures 2a,3a). This pattern may reflect declines in reef water quality from runoff, as increased turbidity would most likely have a greater effect on deeper reef zones due to increasing light attenuation with depth. However, the significant post-1980s declines in the prevalence in stress-tolerant and weedy corals that occurred at the reef crest (but not midslope) zone may reflect higher coral mortality from (1) anthropogenic bleaching in shallower zones that experience greater thermal stress and/or (2) the die-off of the Diadema urchin that prefers shallower reef zones [48].

\section{The role of local and global human stressors}

Although climate change is currently imperiling reef ecosystems globally [49], the early timing of the initial declines in CaribbeanAcropora corals suggests that climate change was not responsible for this first phase of Caribbean coral community transformation. In the Caribbean, anthropogenic ocean warming did not become significant until the 1970s [50-51] and warming-related coral bleaching was not observed until the late 1980s [52]. Our recent analysis of long-term trends in the dominance of A. cervicornis and A. palmatashowed that initial declines in the 1950s and 1960s were unrelated to regional or global stressors (i.e., anthropogenic temperature stress or hurricane exposure; ref 13).

Instead, the early timing of initial changes in Caribbean coral communities implicates long-standing local stressors such as fishing and land-based pollution. However, the paucity of long-term data on fishing effort/reef fish abundance or reef water quality precludes a quantitative assessment of the role of these activities in recent Caribbean-wide reef ecosystem change. Consequently, despite the well-established relationships between hermatypic coral persistence and abundant herbivorous reef fish populations and low-sediment, lownutrient waters [3,53-55], historical fishing and land clearing have been largely ignored in most analyses of Caribbean coral declines [56]. Fortunately, a few longer-term datasets on water quality at various Caribbean reefs provide valuable insights into the role of land-based runoff in coral community change. An analysis of seawater and macroalgae nitrogen content since the 1990s from the Florida Keys implicates land-based nutrients from agriculture and development in the decades-long coral declines within that reef tract [57]. Studies based on historical and paleontological data also suggest that early reef ecosystem declines in Barbados and Panama may be attributed to increases in coastal runoff from historical land clearing for agriculture $[17,58-59]$.

In contrast to the early transformation of Caribbean coral communities following the initial loss of Acropora in the 1950s/1960s, more recent changes since the 1980s/1990s demonstrate the heightened effects of local stressors and climate change acting on reefs simultaneously. Although our study suggests that White Band Disease was not the cause of initial Acropora declines, it confirms that it has unequivocally contributed to the loss of this genus: the second significantAcropora decline observed in our time series in the early 1980s immediately followed the first instances of this disease reported in the late 1970s [9]. Land-based runoff has been shown to exacerbate coral bleaching and disease [57,60-61], suggesting that reef eutrophication played 
a role in the emergence of these morbidities. Similarly, the region-wide declines in stress-tolerant and weedy corals we observed since the 1980s/1990s reveal that local and global stressors are making Caribbean reef environments unsuitable even for those corals with the hardiest of life history strategies. Indeed, recent monitoring efforts have documented declines in several stress-tolerant taxa from bleaching and disease that were initiated two decades ago [62-63] and show that several stress-tolerant species are currently rapidly succumbing to the highly lethal Stony Coral Tissue Loss Disease that does not affect Acropora [64-66]. Monitoring efforts are also documenting declines in weedy corals such as Agaricia due to recent Caribbeanwide bleaching events [67]. Thus, the shifts documented in our 131,000-year record indicate a long history of increasingly stressful environmental conditions on Caribbean reefs that began with local human disturbances and have culminated in the combined effects of local and global change.

\section{Challenges with assessing long-term trends}

To track Caribbean coral community change prior to and since the arrival of humans, we used data from multiple sources, including uplifted fossil reefs, reef matrix cores, qualitative historical data, and underwater survey data. However, the prevalence of most of coral taxa are comparable across the paleo, historical, and early modern time bins, suggesting that overall trends were not artifacts of comparing differing data types (Figures 2,3). Exceptions include (1) the conspicuously lower within-country community dissimilarity observed within the fossil versus non-fossil time bins, which is likely due to the greater time averaging within the former and (2) significant differences in the prevalence of multiple coral taxa between the Pleistocene and Holocene. Significant Pleistocene-Holocene differences included declining prevalence of $A$. cervicornis at the midslope zone and increased prevalence of a number of stress-tolerant and weedy taxa at both zones (Table 2, Figures 2,3). These differences could reflect declining rates of sea level rise during the late Holocene, which would favor increased dominance of more slowly growing species with massive colony forms [68] - a trend we observe in our data from the midslope zone (Figure $3 \mathrm{~b}$ ). Lower A. cervicornis prevalence in the Holocene compared to the Pleistocene could also be a result of inaccurate paleodepth estimates and/or underestimation of $A$. cervicornis abundance from the narrow-diameter core tubes which comprise most of the Holocene data. However, A. palmata dominance increased slightly at the reef crest between the Pleistocene and Holocene, demonstrating that there was no bias against sampling this coral in the Holocene reef cores [13]. Importantly, when data from the Pleistocene and Holocene periods are combined, overall trends in prevalence of coral functional and species groups are largely identical to those with these time periods separated-declines in Acropora prevalence first occurred in the 1960s, followed by increases in stress-tolerant and weedy species in the 1970s and 1980s (Table S6, Figures S3,S4).

Although abundance data allows for a more robust assessment of community composition than presence/absence data, the exceptionally broad temporal, taxonomic, and geographic scales covered in this study necessitated the utilization of the latter. Prevalence does not equal abundance; although we found that the prevalence of stress-tolerant and weedy corals has increased over the most recent decades, the total abundance of living coral has declined by $50-80 \%$ across the Caribbean since the initiation of quantitative surveys in the 1970s [1-2,8]. However, ecological studies show that, on large spatial scales, trends in prevalence (proportion of sites occupied) are correlated with trends in abundance [69-70]. This suggests that the long-term trends shown in this study are reliable proxies of qualitative trends in relative (but not absolute) abundance.

\section{Conservation implications}

The anthropogenic transformation of Caribbean coral communities into their historically novel configurations has widespread consequences for reef ecosystem functioning. First, the loss of competitive Acropora corals represents a massive simplification of reef architectural structure and loss of carbonate production that may compromise the ability of Caribbean reefs to keep pace with anthropogenic sea level rise [71-72]. Second, the simplification of reef architecture has the potential to reduce diversity as well as the overall abundance of reef fish communities [73-74] and coral-associated invertebrates [17]. Third, coral community turnover has reduced the recovery potential of these reefs by selectively removing coral species with high larval dispersal rates (Acropora) and replacing them with species with low larval dispersal rates (Agaricia and Porites 
), limiting the ability of relatively intact reefs to re-seed degraded ones [75]. As climate change impacts accelerate on Caribbean reefs and exacerbate the effects of long-standing local human disturbances, the simultaneous mitigation of both local and global stressors is the only viable path to reef persistence. Indeed, recent studies from the Caribbean and Great Barrier Reef highlight the prospect of enhanced reef resiliency (but not resistance) to climate change impacts when land-based nutrification and overfishing are alleviated [57,76-78].

\section{Acknowledgements}

Many thanks to P. Alcolado, J. Alemu, E. Arias, A. Atkinson, R. Bak, C. Bastidas, P. Blanchon, C. Bouchon, A. Brathwaite, J. Bruno, K. Buchan, P. Bush, C. Caldow, B. Charpentier, M. Chiappone, M. Colella, M. Creary, C. McCoy, A. Croquer, K. De Meyer, P. Dustan, P. Edmunds, D. Fenner, G. Forrester, A. Friedlander, P. Gayle, H. Guzmán, A. Harborne, M. Hardt, Z. Hilis-Starr, E. Hochberg, T. Hughes, W. Jaap, M. Jordan, K. Koltes, J. Lang, Y. Loya, I. Lundgren, C. Manfrino, M. McField, J. Miller, J. Mitchell, P. Mumby, T. Murdoch, I. Nagelkerkan, R. Nemeth, M. Nugues, H. Oxenford, J. Pandolfi, G. Paredes, H. Reyes Bonilla, R. Rodriguez-Martinez, A. Rodriguez-Ramirez, C. Rogers, R. Ruzicka, T. Smith, B. Sommer, B. Steneck, M. Vermeij, and E. Weil for contributing their survey data to the Global Coral Reef Monitoring Network (GCRMN). This study was funded by GCRMN.

\section{Data Accessibility Statement}

All data will be deposited on Dryad.

\section{Competing Interests Statement}

The authors declare that they have no competing interests.

\section{Authors' Contributions}

Cook: Data Curation; Writing - Review and Editing.Cramer: Conceptualization; Data Curation; Methodology; Formal Analysis; Visualization; Writing - Original Draft Preparation; Writing - Review and Editing. Donovan: Data Curation; Formal Analysis; Writing - Review and Editing. Greenstein: Conceptualization; Data Curation; Methodology; Writing - Review and Editing.Jackson: Conceptualization; Project Administration; Resources; Writing - Review and Editing. Korpanty: Data Curation; Writing - Review and Editing. Pandolfi: Conceptualization; Data Curation; Methodology; Writing - Review and Editing.

\section{References}

1. Gardner TA, I. M. Côté, J. A. Gill, A. Grant, A. R. Watkinson (2003) Long-term region-wide declines in Caribbean corals. Science301, 958-960.

2. Jackson, J. B. C., Donovan, M. K., Cramer, K. L., Lam, V. V. (2014). Status and trends of Caribbean coral reefs: 1970-2012. Global Coral Reef Monitoring Network, IUCN, Gland, Switzerland.

3. Hughes TP, M. J. Rodrigues, D. R. Bellwood, D. Ceccarelli, O. Hoegh-Guldberg, L. McCook, N. Moltschaniwskyj, M. S. Pratchett, R. S. Steneck, B. Willis (2007) Phase shifts, herbivory, and the resilience of coral reefs to climate change. Curr. Biol. 17, 360-365.

4. Aronson RB, Precht WF (2001) White-band disease and the changing face of Caribbean coral reefs. Hydrobiologia 460: 25-38.

5. Lessios, H. A., Robertson, D. R., Cubit, J. D. (1984) Spread ofDiadema mass mortality through the Caribbean. Science, 226, 335-337.

6. Jackson JBC (1997) Reefs since Columbus. Coral Reefs, 16, S23-S32.

7. Jackson JBC, et al. (2001) Historical overfishing and the recent collapse of coastal ecosystems. Science, 292, 629-637.

8. Pandolfi JM, et al. (2003) Global trajectories of the long-term decline of coral reef ecosystems. Science, 301(5635), 955-958.

9. Gladfelter WB (1982) White-band disease in Acropora palmata : implications for the structure and growth of shallow reefs. Bull. Mar. Sci. 32, 639-643 
10. Bruckner AW (2002) Proceedings of the Caribbean Acroporaworkshop: potential application of the U.S. Endangered Species Act as a conservation strategy. Silver Spring, MD: NOAA Technical Memorandum NMFS-OPR-24.

11. Bythell J., Pantos O., Richardson L. (2004) White Plague, White Band, and Other "White" Diseases. In: Rosenberg E., Loya Y. (eds) Coral Health and Disease. Springer, Berlin

12. Eakin CM, et al. (2010) Caribbean corals in crisis: Record thermal stress, bleaching, and mortality in 2005. PLOS ONE 5: e13969.

13. Cramer KL, Jackson JB, Donovan MK, Greenstein BJ, Korpanty CA, Cook GM, Pandolfi JM (2020) Widespread loss of Caribbean acroporid corals was underway before coral bleaching and disease outbreaks. Sci. Adv., 6, p.eaax9395.

14. Aronson, R.B., Macintyre, I.G., Wapnick, C.M., ONeill, M.W. (2004) Phase shifts, alternative states, and the unprecedented convergence of two reef systems. Ecology, 85, 1876-1891.

15. Aronson, R.B., Macintyre, I.G., Lewis, S.A., Hilbun, N.L. (2005) Emergent zonation and geographic convergence of coral reefs. Ecology, 86, 2586-2600.

16. Green, D. H., Edmunds, P. J., Carpenter, R. C. (2008) Increasing relative abundance of Porites astreoides on Caribbean reefs mediated by an overall decline in coral cover. Mar. Ecol. Prog. Ser. 359:1-10

17. Cramer, K.L., Jackson, J.B., Angioletti, C.V., Leonard-Pingel, J., Guilderson, T.P. (2012) Anthropogenic mortality on coral reefs in Caribbean Panama predates coral disease and bleaching. Ecol. Lett. 15, 561-567.

18. Pandolfi, J.M., Jackson, J.B. (2006) Ecological persistence interrupted in Caribbean coral reefs. Ecol. Lett. 9, 818-826.

19. Khan NS et al. (2017) Drivers of Holocene sea-level change in the Caribbean. Quat. Sci. Rev. 155, 13-36.

20. Milliman JD (1969) Four southwestern Caribbean atolls: Courtown Cays, Albuquerque Cays, Roncador Bank and Serrana Bank. Atoll Res. Bull. 129, 1-46.

21. Knowlton, N., Weil, E., Weigt, L.A., Guzman, H.M., 1992. Sibling species in Montastraea annularis , coral bleaching, and the coral climate record. Science, 255, pp.330-333.

22. Budd, A.F., Fukami, H., Smith, N.D., Knowlton N. (2012) Taxonomic classification of the reef coral family Mussidae (Cnidaria: Anthozoa: Scleractinia). Zool. J. Linn. Soc. 166, 465-529.

23. Darling, E. S., Alvarez-Filip, L., Oliver, T. A., McClanahan, T. R., Cote, I. M. (2012) Evaluating life-history strategies of reef corals from species traits. Ecol. Lett. 15, 1378-1386.

24. Grime, J.P. (1977) Evidence for the existence of three primary strategies in plants and its relevance to ecological and evolutionary theory. Am. Nat., 111, 1169-1194.

25. Grime, J.P. (1979) Plant strategies and vegetation processes.

26. Smith, S.R. (1992) Patterns of coral recruitment and post-settlement mortality on Bermuda's reefs: comparisons to Caribbean and Pacific reefs. Amer. Zool. 32, 663-673.

27. Hardt, M.J., 2007. Human impacts on Caribbean coral reef ecosystems (Doctoral dissertation, UC San Diego).

28. Hughes TP, Jackson JBC (1985) Population dynamics and life histories of foliaceous corals. Ecol. Monogr. 55, 141-166.

29. Jackson, J.B.C, (1992) Pleistocene perspectives on coral reef community structure. Ame. Zool. 32, 719-731.

30. Pandolfi, J.M., Jackson, J.B. (2001) Community structure of Pleistocene coral reefs of Curacao, Netherlands Antilles. Ecol. Monogr. 71, 49-67.

31. Loya, Y., Sakai, K., Yamazato, K., Nakano, Y., Sambali, H, van Woesik, R., 2001. Coral bleaching: the winners and the losers. Ecol. Lett. 4, 122-131.

32. Dube, C.E. (2016) Life history of Millepora hydrocorals: new ecological and evolutionary perspectives from population genetic approaches (Doctoral dissertation, Paris, EPHE).

33. McClanahan TR, Muthiga NA (1998) An ecological shift in a remote coral atoll of Belize over 25 years. Environ. Conserv. 25, 122-130.

34. Geister, J. (1977) The influence of wave exposure on the ecological zonation of Caribbean coral reefs. 
Proc. Third International Coral Reef Symposium 1 23-29.

35. Rutzler K, Macintyre IG (1982) The habitat distribution and community structure of the barrier reef complex at Carrier Bow Cay, Belize. Pages 9-45 in K. Rutzler, Macintyre IG (editors), The Atlantic Barrier Reef ecosystem at Carrie Bow Cay, Belize. Smithsonian, Washington DC

36. Lang J. (1973) Interspecific aggression by scleractinian corals. 2. Why the race is not only to the swift. Bull. Mar. Sci. 23, 260-279.

37. Bak, R.P.M., Engel, M.S. (1979) Distribution, abundance and survival of juvenile hermatypic corals (Scleractinia) and the importance of life history strategies in the parent coral community. Mar. Biol. 54, 341-352.

38. Hughes TP (1985) Life histories and population dynamics of early successional corals. 5th International Coral Reef Congress, 101-106

39. Jaccard, P. (1912) The distribution of the flora in the alpine zone. New Phytologist, 11, 37-50.

40. R Core Team (2018) R: A language and environment for statistical computing. R Foundation for Statistical Computing, Vienna, Austria.

41. Benjamini Y, Hochberg Y (1995) Controlling the false discovery rate: a practical and powerful approach to multiple testing. J. Roy. Stat. Soc. B. Met. 289-300

42. Randall C. J., R. van Woesik (2015) Contemporary white-band disease in Caribbean corals driven by climate change. Nat. Clim. Chang .5 , 375-379.

43. Lasker HR, Peters EC, Coffroth MA (1984) Bleaching of reef coelenterates in the San Blas Islands, Panama. Coral Reefs 3:183-190.

44. Aronson, R. B., Precht, W. F., Macintyre, I. G., Murdoch, T. J. (2000) Ecosystems: Coral bleach-out in Belize. Nature, 405, 36.

45. Gates, R. T. (1990) Seawater temperature and sublethal coral bleaching in Jamaica. Coral Reefs, 8, 193-197.

46. Vega Thurber RL et al. (2020) Deciphering coral disease dynamics: Integrating host, microbiome, and the changing environment. Front. Ecology. Evol., 8, 402.

47. Burman, S.G., Aronson, R.B, van Woesik, R., 2012. Biotic homogenization of coral assemblages along the Florida reef tract. Mar. Ecol. Progr. Ser. 467, 89-96.

48. Lessios, H.A., Cubit, J.D., Robertson, D.R., Shulman, M.J., Parker, M.R., Garrity, S.D. Levings, S.C., (1984) Mass mortality ofDiadema antillarum on the Caribbean coast of Panama. Coral Reefs, 3, 173-182.

49. Hughes TP et al. (2018) Spatial and temporal patterns of mass bleaching of corals in the Anthropocene. Science, 359, 80-83.

50. Sheppard C, R. Rioja-Nieto (2005) Sea surface temperature 1871-2099 in 38 cells in the Caribbean region. Mar. Environ. Res. 60, 389-396.

51. Knutson TR, T. L. Delworth, K. W. Dixon, I. M. Held, J. Lu, V. Ramaswamy, M. D. Schwarzkopf (2006) Assessment of Twentieth-Century Regional Surface Temperature Trends Using the GFDL CM2 Coupled Models. J. Climate 19, 1624-1651.

52. Glynn PW (1993) Coral reef bleaching: ecological perspectives. Coral Reefs 12, 1-17.

53. Randall JE (1961) Overgrazing of algae by herbivorous marine fishes.Ecology 42, 812-812.

54. Fabricius, K.E. (2005) Effects of terrestrial runoff on the ecology of corals and coral reefs: review and synthesis. Mar. Pollut. Bull. 50, 125-146

55. Cramer KL, A. O'Dea, T. R. Clark, J. Zhao, R. D. Norris (2017) Prehistorical and historical declines in Caribbean coral reef accretion rates driven by loss of parrotfish. Nat. Commun.8 , 14160.

56. Abelson A (2019) Are we sacrificing the future of coral reefs on the altar of the "climate change" narrative? ICES J. Mar. Sci.

57. Lapointe, B.E., Brewton, R.A., Herren, L.W., Porter, J.W., Hu, C. (2019) Nitrogen enrichment, altered stoichiometry, and coral reef decline at Looe Key, Florida Keys, USA: a 3-decade study. Mar. Biol. $166,108$.

58. Lewis JB (1984) The Acropora inheritance: a reinterpretation of the development of fringing reefs in Barbados, West Indies. Coral Reefs 3: 117-122 
59. Cramer KL, O'Dea A, Leonard-Pingel JS, Norris RD. 2019. Millennial-scale change in Caribbean coral reef ecosystem structure and the role of human and natural disturbance. Ecography.

60. Bruno, J.F., Petes, L.E., Harvell, C.D., A. Hettinger (2003) Nutrient enrichment can increase the severity of coral diseases. Ecol. Lett. 6, 1056-1061.

61. Wiedenmann J, D'Angelo C, Smith EG, Hunt AN, Legirt FE, Postle AD, Achterberg EP (2013) Nutrient enrichment can increase the susceptibility of reef corals to bleaching. Nat. Clim. Change 3,160-164.

62. Edmunds, P.J., Elahi, R. (2007) The demographics of a 15-year decline in cover of the Caribbean reef coral Montastraea annularis . Ecol. Monogr. 77, 3-18.

63. Harvell, D., Jordán-Dahlgren, E., Merkel, S., Rosenberg, E., Raymundo, L., Smith, G., Weil, E., Willis, B., 2007. Coral disease, environmental drivers, and the balance between coral and microbial associates. Oceanography, 20, 172-195.

64. Weil, E., Cróquer, A., Urreiztieta, I. (2009) Yellow band disease compromises the reproductive output of the Caribbean reef-building coral Montastraea faveolata (Anthozoa, Scleractinia). Dis. of Aquat. Org. 87, 45-55.

65. Precht, W.F., Gintert, B.E., Robbart, M.L., Fura, R., van Woesik, R. (2016) Unprecedented diseaserelated coral mortality in Southeastern Florida. Scientific Reports, 6, p.31374.

66. van Woesik R, Randall, C.J. (2017) Coral disease hotspots in the Caribbean. Ecosphere, 8, p.e01814.

67. Walton, C., Hayes, N.K. and Gilliam, D.S. (2018) Impacts of a regional, multi-year, multi-species coral disease outbreak in Southeast Florida. Front. Mar. Sci, 5, p.323.

68. Hongo C (2012) Holocene key coral species in the Northwest Pacific: Indicators of reef formation and reef ecosystem responses to global climate change and anthropogenic stresses in the near future. Quat. Sci. Rev. 35, 82-99.

69. Weber D, Hinterman U, Zangger A (2004) Scale and trends in species richness: considerations for monitoring biological diversity for political purposes. Global Ecological Biogeography 13:97-104.

70. MacKenzie DI, Sutton N, Kawanishi K, Bailey LL (2005) Improving inferences in population studies of rare species that are detected imperfectly. Ecology 86:1101-1113.

71. Alvarez-Filip L., Dulvy, N. K., Gill, J. A., Côté, I. M., Watkinson, A. R. (2009) Flattening of Caribbean coral reefs: region-wide declines in architectural complexity. Proc. Royal Soc. B, rspb20090339.

72. Perry, C. T., Steneck, R. S., Murphy, G. N., Kench, P. S., Edinger, E. N., Smithers, S. G., Mumby, P. J. (2014) Regional-scale dominance of non-framework building corals on Caribbean reefs affects carbonate production and future reef growth. Global Change Biology.

73. Paddack MJ et al. (2009) Recent region-wide declines in Caribbean reef fish abundance. Curr. Biol., 19, 590-595.

74. Richardson, L.E., Graham, N.A., Pratchett, M.S., Eurich, J.G, Hoey, A.S. (2018) Mass coral bleaching causes biotic homogenization of reef fish assemblages. Global Change Biology, 24, 3117-3129.

75. Knowlton, N. (2001) The future of coral reefs. Proc. Nat. Acad. Sci. USA, 98, 5419-5425.

76. Mellin, C., Aaron MacNeil, M., Cheal, A.J., Emslie, M.J., Julian Caley, M. (2016) Marine protected areas increase resilience among coral reef communities. Ecology Letters, 19, 629-637.

77. MacNeil, M.A., Mellin, C., Matthews, S., Wolff, N.H., McClanahan, T.R., Devlin, M., Drovandi, C., Mengersen, K., Graham, N.A. (2019) Water quality mediates resilience on the Great Barrier Reef. Nat. Ecol. Evol., 3, 620-627.

78. Steneck R, Arnold SN, Boenish R, De Leon R, Mumby PJ, Rasher DB, Wilson M (2019) Managing recovery resilience in coral reefs against climate-induced bleaching and hurricanes: a 15 year case study from Bonaire, Dutch Caribbean. Front. Mar. Sci, 6, p.265.

Table 1. Coral life history groups and their defining characteristics. Rankings compiled from data references listed in Table S1. Growth rate is linear extension rate, reproductive output is larval recruitment rate. See Table S3 for description of methods used to compute rankings.

\begin{tabular}{lllll}
\hline Life history group & Species group & Colony morphology & Growth rate & Reprod. mode \\
\hline Competitive & Acropora cervicornis & large branching & fast & spawner
\end{tabular}




\begin{tabular}{lllll}
\hline Life history group & Species group & Colony morphology & Growth rate & Reprod. mode \\
\hline & Acropora palmata & large branching & fast & spawner \\
& (Millepora spp.) & plating and branching & fast & spawner \\
Stress-tolerant & Colpophyllia natans & domed & moderate & spawner \\
& Diploria spp. & domed & moderate & spawner \\
& Meandrina spp. & domed & slow & spawner \\
& Montastrea cavernosa & domed & moderate & spawner \\
& (Orbicella spp.) & domed & moderate & spawner \\
& Siderastrea spp. & domed & slow & spawner $(S$. siderea); brooder $($ S. rad \\
& Stephanocoenia spp. & domed & moderate & spawner \\
& Agaricia spp. & plating and foliose & slow & brooder \\
& Branching Porites spp. & small branching & fast & brooder \\
& Porites astreoides & domed & slow & brooder \\
& Madracis spp. & small branching & moderate & brooder \\
\hline
\end{tabular}

Table 2. Trends in prevalence of coral life history and taxonomic groups. Trends deemed significant at the $\mathrm{P}<0.05$ level.

\begin{tabular}{|c|c|c|c|c|c|c|}
\hline Zone & $\begin{array}{l}\text { Life history } \\
\text { group }\end{array}$ & Taxon & $\begin{array}{l}\text { Overall change } \\
(*=\operatorname{sig})\end{array}$ & $\begin{array}{l}\text { Earliest sig. } \\
\text { change relative } \\
\text { to Pleistocene }\end{array}$ & $\begin{array}{l}\text { Peak in } \\
\text { prevalence }\end{array}$ & $\begin{array}{l}\text { Earliest sig. } \\
\text { decline from } \\
\text { peak }\end{array}$ \\
\hline \multirow[t]{15}{*}{ Crest } & Competitive & (without & $87-13 \% *$ & Holocene & Pleistocene & Holocene \\
\hline & & $\begin{array}{l}\text { Millepora) } \\
\text { (with } \\
\text { Millepora) }\end{array}$ & $54-38 \% *$ & 1960-1969 & 1500-1959 & 1960-1969 \\
\hline & & $\begin{array}{l}\text { Acropora } \\
\text { cervicornis }\end{array}$ & $69-9 \% *$ & 1960-1969 & Pleistocene & 1960-1969 \\
\hline & & $\begin{array}{l}\text { Acropora } \\
\text { palmata }\end{array}$ & $89-24 \% *$ & Holocene & Pleistocene & Holocene \\
\hline & & $\begin{array}{l}\text { Millepora } \\
\text { spp. }\end{array}$ & $8-88 \% *$ & 1500-1959 & 1995-1999 & - \\
\hline & $\begin{array}{l}\text { Stress- } \\
\text { tolerant }\end{array}$ & & $22-37 \% *$ & 1985-1989 & 1985-1989 & 1990-1994 \\
\hline & & $\begin{array}{l}\text { Colpophyllia } \\
\text { natans }\end{array}$ & $23-28 \%$ & - & 1995-1999 & $2005-2011$ \\
\hline & & $\begin{array}{l}\text { Diploria } \\
\text { spp. }\end{array}$ & $65-58 \%$ & Holocene & 1985-1989 & 1995-1999 \\
\hline & & $\begin{array}{l}\text { Meandrina } \\
\text { spp. }\end{array}$ & $8-7 \%$ & - & 1980-1984 & - \\
\hline & & $\begin{array}{l}\text { Montastrea } \\
\text { cavernosa }\end{array}$ & $34-33 \%$ & Holocene & 1995-1999 & - \\
\hline & & $\begin{array}{l}\text { Orbicella } \\
\text { spp. }\end{array}$ & $69-55 \%$ & 1990-1994 & Pleistocene & 1990-1994 \\
\hline & & $\begin{array}{l}\text { Siderastrea } \\
\text { spp. }\end{array}$ & $15-73 \% *$ & 1980-1984 & 1985-1989 & $2000-2004$ \\
\hline & & $\begin{array}{l}\text { Stephanocoenia } \\
\text { spp. }\end{array}$ & $2-27 \%$ & 1985-1989 & 1985-1989 & 1995-1999 \\
\hline & Weedy & & $1-48 \% *$ & - & 1985-1989 & 1990-1994 \\
\hline & & $\begin{array}{l}\text { Agaricia } \\
\text { spp. }\end{array}$ & $20-57 \% *$ & $1980-1984$ & 1985-1989 & 1995-1999 \\
\hline
\end{tabular}




\begin{tabular}{|c|c|c|c|c|c|c|}
\hline Zone & $\begin{array}{l}\text { Life history } \\
\text { group }\end{array}$ & Taxon & $\begin{array}{l}\text { Overall change } \\
(*=\operatorname{sig})\end{array}$ & $\begin{array}{l}\text { Earliest sig. } \\
\text { change relative } \\
\text { to Pleistocene }\end{array}$ & $\begin{array}{l}\text { Peak in } \\
\text { prevalence }\end{array}$ & $\begin{array}{l}\text { Earliest sig. } \\
\text { decline from } \\
\text { peak }\end{array}$ \\
\hline & & $\begin{array}{l}\text { branching } \\
\text { Porites spp. }\end{array}$ & $33-69 \% *$ & 1970-1979 & 1985-1989 & 1995-1999 \\
\hline & & Madracis & $>1-6 \%$ & - & $1980-1984$ & 1985-1989 \\
\hline & & $\begin{array}{l}\text { spp. } \\
\text { Porites } \\
\text { astreoides }\end{array}$ & $17-78 \% *$ & 1960-1969 & 1985-1989 & - \\
\hline \multirow[t]{19}{*}{ Slope } & Competitive & (without & $80-4 \% *$ & Holocene & Pleistocene & Holocene \\
\hline & & $\begin{array}{l}\text { Millepora) } \\
\text { (with }\end{array}$ & $44-12 \% *$ & $1960-1969$ & 1500-1959 & Holocene \\
\hline & & Millepora) & & & & \\
\hline & & $\begin{array}{l}\text { Acropora } \\
\text { cervicornis }\end{array}$ & $87-8 \% *$ & Holocene & Pre-contact & Holocene \\
\hline & & $\begin{array}{l}\text { Acropora } \\
\text { palmata }\end{array}$ & $58-1 \% *$ & Holocene & $1500-1959$ & Holocene \\
\hline & & $\begin{array}{l}\text { Millepora } \\
\text { spp. }\end{array}$ & $5-66 \% *$ & 1995-1999 & 2005-2011 & $\mathrm{N} / \mathrm{A}$ \\
\hline & $\begin{array}{l}\text { Stress- } \\
\text { tolerant }\end{array}$ & & $8-71 \%$ & Holocene & $1500-1959$ & - \\
\hline & & $\begin{array}{l}\text { Colpophyllia } \\
\text { natans }\end{array}$ & $6-55 \% *$ & 1970-1979 & 1995-1999 & 2005-2011 \\
\hline & & $\begin{array}{l}\text { Diploria } \\
\text { spp. }\end{array}$ & $57-68 \%$ & 1980-1984 & 1960-1969 & - \\
\hline & & $\begin{array}{l}\text { Meandrina } \\
\text { spp. }\end{array}$ & $6-43 \% *$ & 1985-1989 & 1995-1999 & - \\
\hline & & $\begin{array}{l}\text { Montastrea } \\
\text { cavernosa }\end{array}$ & $19-82 \% *$ & 1970-1979 & 2005-2011 & $\mathrm{N} / \mathrm{A}$ \\
\hline & & $\begin{array}{l}\text { Orbicella } \\
\text { spp. }\end{array}$ & $96-86 \%$ & 1985-1989 & 1500-1959 & - \\
\hline & & $\begin{array}{l}\text { Siderastrea } \\
\text { spp. }\end{array}$ & $30-87 \% *$ & $1980-1984$ & $2000-2004$ & - \\
\hline & & $\begin{array}{l}\text { Stephanocoenia } \\
\text { spp. }\end{array}$ & $1-59 \% *$ & Holocene & $2005-2011$ & $\mathrm{~N} / \mathrm{A}$ \\
\hline & Weedy & & 9-70\%* & 1960-1969 & 1990-1994 & decline \\
\hline & & $\begin{array}{l}\text { Agaricia } \\
\text { spp. }\end{array}$ & $6-77 \% *$ & Holocene & 1990-1994 & 2005-2011 \\
\hline & & $\begin{array}{l}\text { Branching } \\
\text { Porites spp. }\end{array}$ & $12-66 \% *$ & 1970-1979 & 1990-1994 & 1995-1999 \\
\hline & & $\begin{array}{l}\text { Madracis } \\
\text { spp. }\end{array}$ & $6-40 \% *$ & 1970-1979 & 1990-1994 & - \\
\hline & & $\begin{array}{l}\text { Porites } \\
\text { astreoides }\end{array}$ & $18-87 \% *$ & 1970-1979 & 2000-2004 & - \\
\hline
\end{tabular}



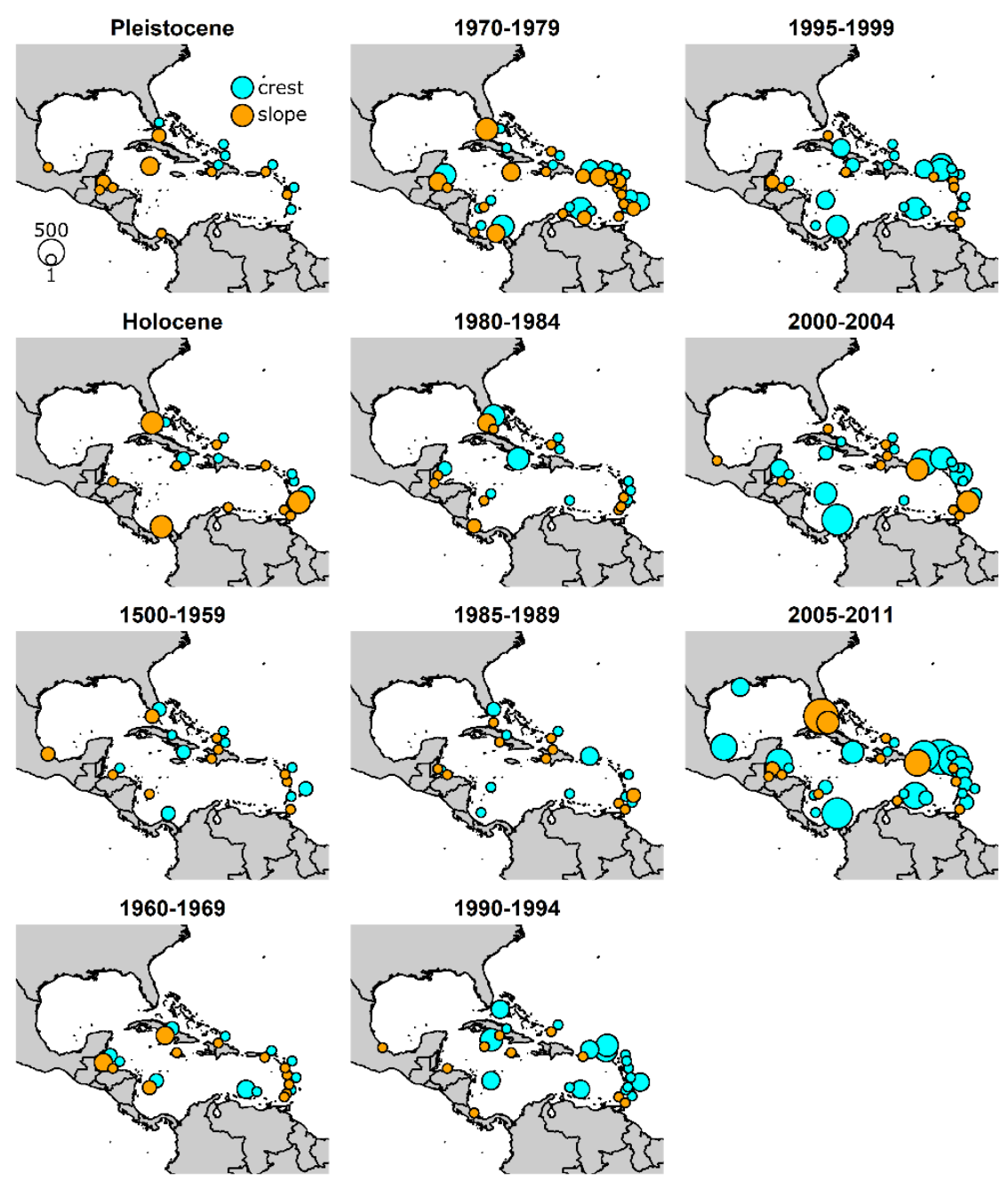

Figure 1. Distribution of presence/absence data for common Caribbean coral taxa. Size of circle proportional to total number of surveys across both reef zones and all bins combined (range $=1-541$ ).
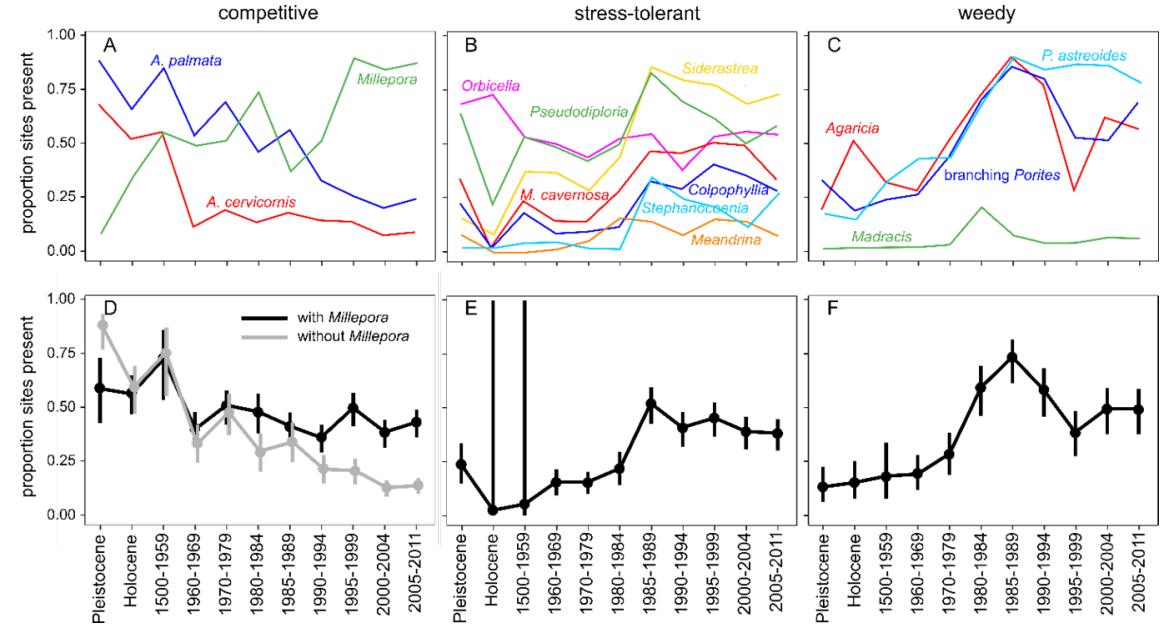
Figure 2. Prevalence of coral life history and species groups since the pre-human period at reef crest zone. (D-F) are values with all species within a life history group considered together. Vertical bars are $95 \%$ confidence intervals (not included for individual species for clarity of plot interpretation).
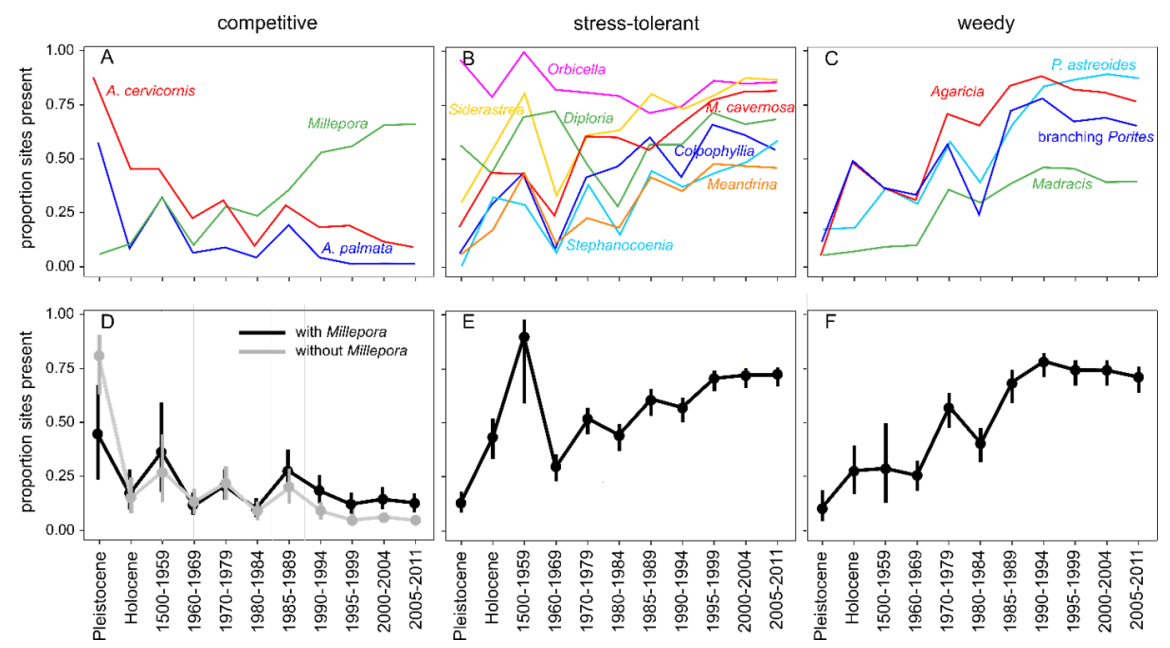

Figure 3. Prevalence of coral life history and species groups since the pre-human period at midslope zone. (D-F) are values with all species within a life history group considered together. Vertical bars are $95 \%$ confidence intervals (not included for individual species for clarity of plot interpretation.

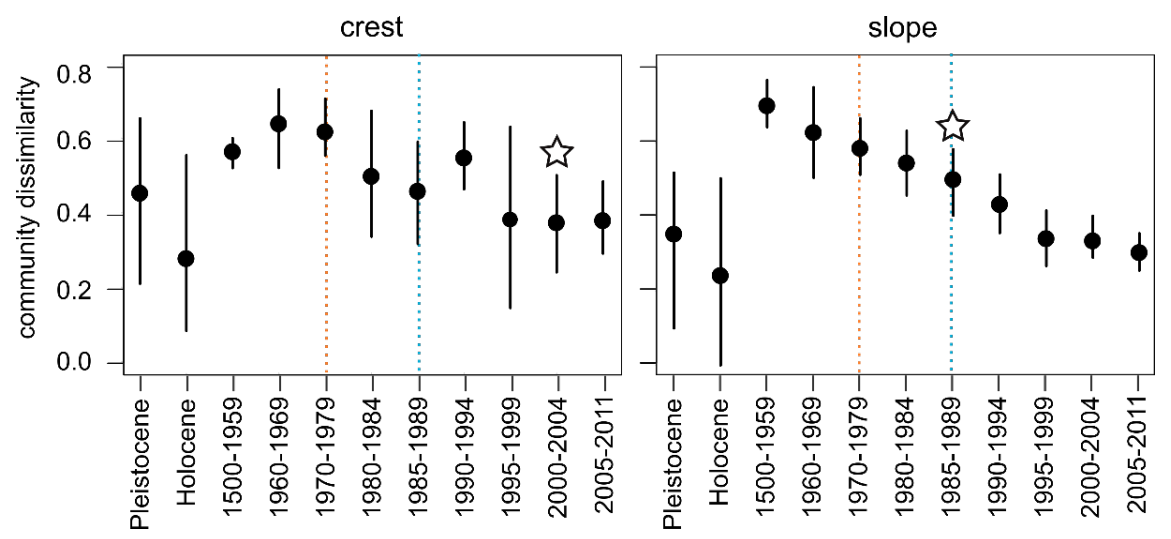

Figure 4. Within-country dissimilarity of Caribbean coral communities since the pre-human period. Orange lines indicate first documented instances of White Band Disease; blue lines indicate first documented instances of widespread coral bleaching and the period following the die-off of keystone herbivore urchin Diadema antillarum. Stars indicate earliest significant change relative to baseline period 1500-1959.

\section{SUPPORTING INFORMATION}

Table S1 . Data sources and number of surveys within each country and time bin containing presence-absence data for all species within at least one life history group. Numbers are sum of sites surveyed within reef crest and/or midslope zone. (Table and references located in separate .xls file).

Table S2. References and methods utilized to calculate rankings for various coral life history traits. (Table and references located in separate .xls file). 
Table S3 . Number of reef sites with presence/absence data for all 14 common coral taxa at reef crest zone.

\begin{tabular}{|c|c|c|c|c|c|c|c|c|c|}
\hline Country & Pleist. & Holo. & $1500-1959$ & $1960-1969$ & $1970-1979$ & $1980-1984$ & $1985-1989$ & $1990-1994$ & 1995 \\
\hline Antigua \& Barbuda & 1 & & & & & & & & \\
\hline Bahamas & 1 & & & & 2 & & & & 3 \\
\hline Barbados & 6 & & 2 & 1 & 3 & 22 & 5 & & 1 \\
\hline Belize & 2 & 9 & & 7 & 8 & 1 & 1 & 1 & 5 \\
\hline British Virgin Islands & & & & & 3 & & & & \\
\hline Cayman Islands & 17 & & & 26 & 4 & & 1 & & \\
\hline Colombia & & & & 6 & 1 & 1 & & 6 & \\
\hline Costa Rica & & & & & & 6 & & & \\
\hline Cuba & & & & 11 & & & & 1 & 1 \\
\hline Dominican Republic & 2 & 2 & & 1 & 2 & & & & \\
\hline Dutch Caribbean & 1 & & & 4 & 6 & & 1 & & \\
\hline Florida & & 3 & & & 10 & 13 & 1 & 51 & 95 \\
\hline Guadel. \& Martinique & & 1 & & & 5 & & 1 & & \\
\hline \multicolumn{10}{|l|}{ Grenada } \\
\hline Honduras & & & & & & & 2 & & \\
\hline Jamaica & & & 7 & 1 & 4 & & & & 4 \\
\hline Mexico & 2 & 17 & 4 & 23 & 4 & 17 & 7 & 1 & 1 \\
\hline Panama & & 4 & & & 8 & & 93 & 101 & 95 \\
\hline Puerto Rico & & 10 & & 5 & 3 & & & & \\
\hline St. Lucia & & & & & 1 & & & & \\
\hline St. Vinc. \& Grenadines & & & & 2 & 2 & & & & \\
\hline Trinidad \& Tobago & & & & & & 5 & & & \\
\hline US Virgin Islands & & 17 & 1 & & 8 & 6 & 20 & 14 & \\
\hline Venezuela & & & & 2 & 5 & & & & 1 \\
\hline Total & 32 & 63 & 14 & 89 & 79 & 71 & 132 & 175 & 206 \\
\hline
\end{tabular}

Table S4 . Number of reef sites with presence/absence data for 14 common coral taxa at midslope zone.

\begin{tabular}{|c|c|c|c|c|c|c|c|c|c|}
\hline Country & Pleist. & Holo. & $1500-1959$ & $1960-1969$ & $1970-1979$ & $1980-1984$ & $1985-1989$ & $1990-1994$ & 1995 \\
\hline Bahamas & 7 & 0 & 1 & 6 & 1 & & & 10 & \\
\hline Barbados & 7 & 1 & 3 & & 7 & 2 & & 11 & 2 \\
\hline Belize & & 12 & & 6 & 19 & 3 & 1 & 1 & 52 \\
\hline British Virgin Islands & & & & & 2 & & & 22 & 40 \\
\hline Cayman Islands & & & & 32 & 2 & & 3 & 39 & 7 \\
\hline Colombia & 1 & & & 5 & 2 & 2 & & 4 & 14 \\
\hline Costa Rica & & & & & & 7 & & 1 & \\
\hline Cuba & & & & 7 & & & & 2 & 12 \\
\hline Dominica & & & & & & & & & \\
\hline Dominican Republic & 2 & 2 & & & 4 & & & & 2 \\
\hline Dutch Caribbean & & 4 & & 4 & 17 & 92 & & 15 & 14 \\
\hline Florida & 1 & 5 & 1 & & 45 & 10 & 1 & 68 & 181 \\
\hline Guadel. \& Martinique & & & & & 3 & & & & \\
\hline Grenada & & & & & 3 & & & & \\
\hline Haiti & 2 & & & & & & & & \\
\hline Honduras & & & & & & & 2 & & 2 \\
\hline
\end{tabular}




\begin{tabular}{|c|c|c|c|c|c|c|c|c|c|}
\hline Country & Pleist. & Holo. & $1500-1959$ & 1960-1969 & $1970-1979$ & $1980-1984$ & $1985-1989$ & 1990-1994 & 1995 \\
\hline Jamaica & & & 2 & 2 & 16 & 9 & 16 & & 8 \\
\hline Mexico & & 1 & & 26 & 5 & 30 & 22 & 4 & \\
\hline Nicaragua & & & & & & & & 2 & 3 \\
\hline Panama & & & & & 12 & & 72 & 53 & 43 \\
\hline Puerto & & & & 1 & 6 & & & 8 & 13 \\
\hline St. Kitts \& Nevis & & & & & & & & & \\
\hline St. Lucia & & & & & 2 & & & & \\
\hline St. Vinc. \& Grenadines & & & & & 5 & & & & \\
\hline Turks \& Caicos & & & & & & & & & 1 \\
\hline Trinidad \& Tobago & & & & & 1 & 10 & & 1 & 4 \\
\hline U.S. Virgin Islands & & 3 & & & 5 & 16 & 6 & 22 & 15 \\
\hline Total & 20 & 28 & 7 & 89 & 157 & 181 & 123 & 263 & 413 \\
\hline
\end{tabular}

Table S5. Trends in competitive and stress-tolerant life history groups with Orbicella classified as a competitive species. Trends deemed significant at the $\mathrm{P}<0.05$ level.

\begin{tabular}{|c|c|c|c|c|c|}
\hline Zone & $\begin{array}{l}\text { Life history } \\
\text { group }\end{array}$ & $\begin{array}{l}\text { Overall change } \\
\left(*^{*}=\operatorname{sig}\right)\end{array}$ & $\begin{array}{l}\text { Earliest sig. } \\
\text { change relative } \\
\text { to Pleistocene }\end{array}$ & $\begin{array}{l}\text { Peak in } \\
\text { prevalence }\end{array}$ & $\begin{array}{l}\text { Earliest sig. } \\
\text { decline from } \\
\text { peak }\end{array}$ \\
\hline \multirow[t]{3}{*}{ Crest } & $\begin{array}{l}\text { Competitive } \\
\text { (without } \\
\text { Millepora) }\end{array}$ & $80-31 \% *$ & Holocene & Pleistocene & Holocene \\
\hline & $\begin{array}{l}\text { Competitive } \\
\text { (with } \\
\text { Millepora) }\end{array}$ & $57-46 \%$ & $1960 \mathrm{~s}$ & $1500-1959$ & 1960-1969 \\
\hline & Stress-tolerant & $18-31 \% *$ & Holocene & $1985-1989$ & 1990-1994 \\
\hline \multirow[t]{3}{*}{ Midslope } & $\begin{array}{l}\text { Competitive } \\
\text { (without } \\
\text { Millepora) }\end{array}$ & $90-18 \% *$ & Holocene & $1500-1959$ & - \\
\hline & $\begin{array}{l}\text { Competitive } \\
\text { (with Millepora) }\end{array}$ & $69-26 \% *$ & Holocene & $1500-1959$ & 1980-1984 \\
\hline & Stress-tolerant & $3-67 \% *$ & Holocene & $2005-2011$ & $\mathrm{~N} / \mathrm{A}$ \\
\hline
\end{tabular}

Table S6. Trends in coral life history groups with Pleistocene and Holocene periods combined into a single "Pre-contact" time bin.Trends deemed significant at the $\mathrm{P}<0.05$ level.

\begin{tabular}{lllll}
\hline & & \multicolumn{2}{l}{$\begin{array}{l}\text { Earliest sig. change } \\
\text { relative to } \\
\text { Pleistocene }\end{array}$} & Peak in prevalence \\
\hline Crest & Life history group & sig) & $1960-1969$ & $1500-1959$ \\
& $\begin{array}{l}\text { Competitive } \\
\text { (without Millepora) }\end{array}$ & $67-13 \%^{*}$ & $1960-1969$ & $1500-1959$ \\
& & & \\
& $\begin{array}{l}\text { Competitive (with } \\
\text { Millepora) }\end{array}$ & $51-38 \%^{*}$ & $1985-1989$ & $1985-1989$ \\
Stress-tolerant & $14-37 \%^{*}$ & $1970-1979$ & $1985-1989$ \\
Midslope & $\begin{array}{l}\text { Weedy } \\
\text { Competitive }\end{array}$ & $15-48 \%^{*}$ & $1960-1969$ & Pre-contact \\
& (without Millepora) & & &
\end{tabular}




\begin{tabular}{|c|c|c|c|c|}
\hline Zone & Life history group & $\begin{array}{l}\text { Overall change }\left(^{*}=\right. \\
\text { sig) }\end{array}$ & $\begin{array}{l}\text { Earliest sig. change } \\
\text { relative to } \\
\text { Pleistocene }\end{array}$ & Peak in prevalence \\
\hline & $\begin{array}{l}\text { Competitive (with } \\
\text { Millepora) }\end{array}$ & $27-12 \% *$ & $1960-1969$ & $1500-1959$ \\
\hline & Stress-tolerant & $37-71 \%$ & 1970-1979 & $2005-2011$ \\
\hline & Weedy & $20-70 \% *$ & 1970-1979 & 1990-1994 \\
\hline
\end{tabular}
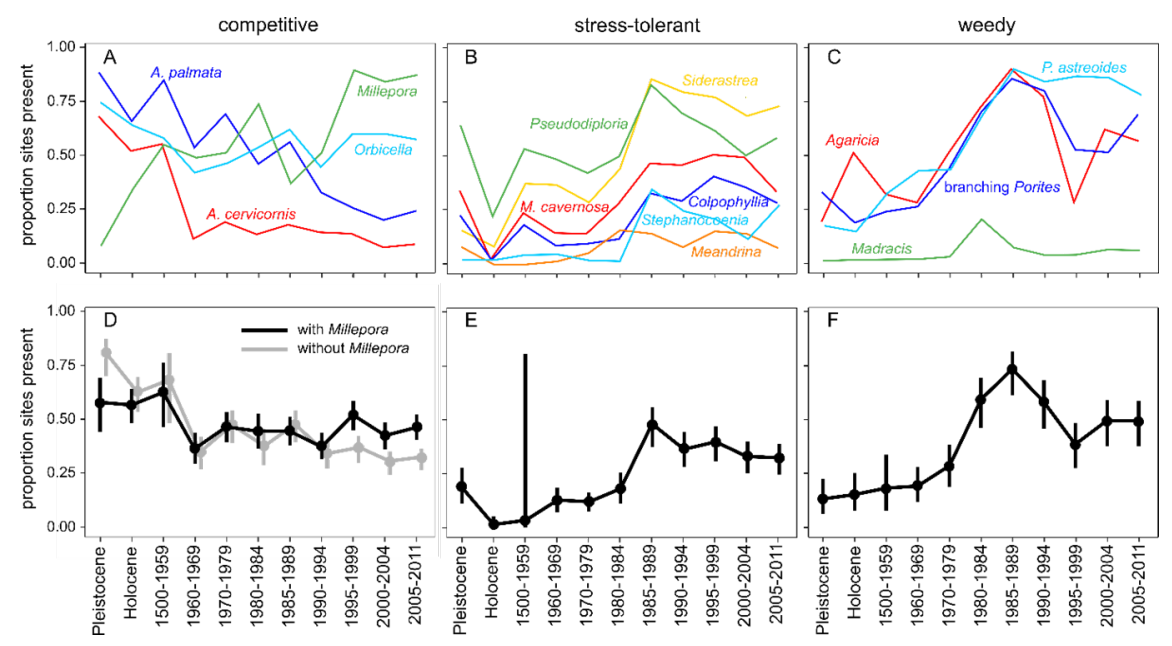

Figure S1. Prevalence of coral life history and species groups since humans at reef crest zone, with Orbicella included in competitive life history group.
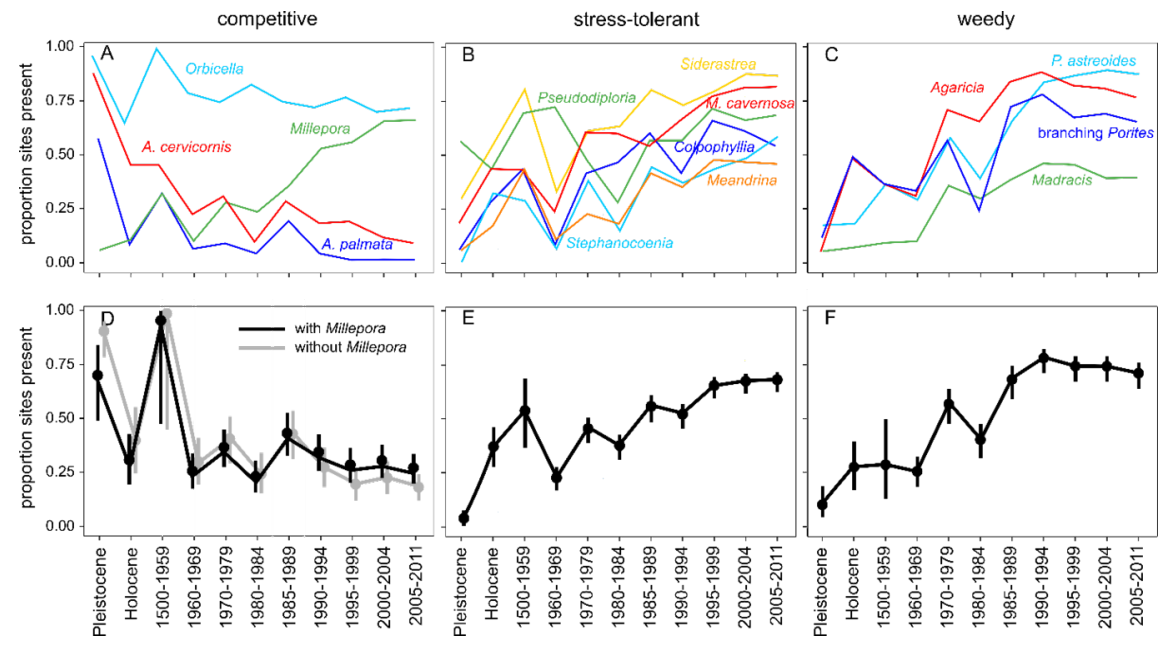

Figure S2. Prevalence of coral life history and species groups since humans at midslope zone, with Orbicella included in competitive life history group. 

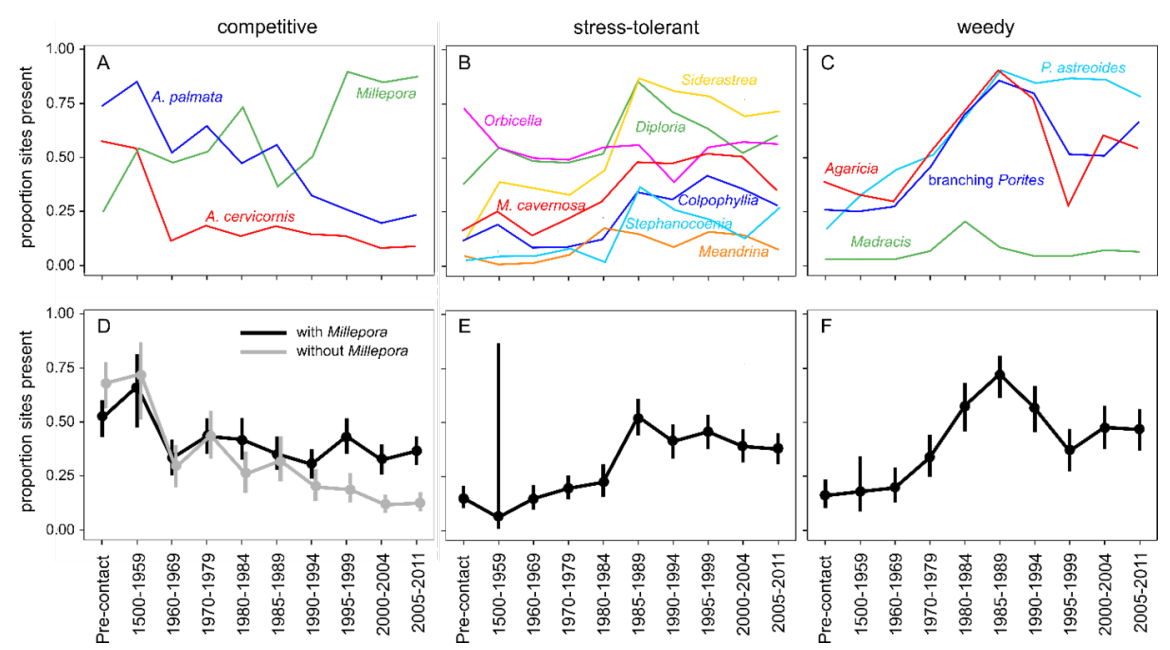

Figure S3. Prevalence of coral life history and species groups since humans at reef crest zone, with Pleistocene and Holocene combined into "pre-contact" time bin.
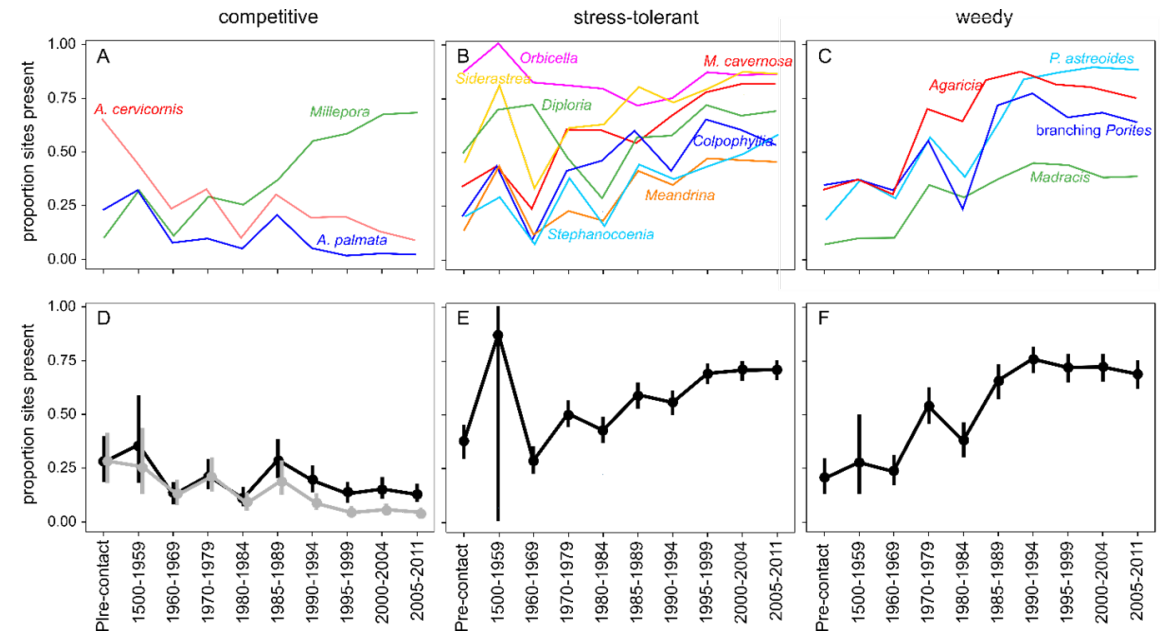

Figure S4. Prevalence of coral life history and species groups since humans at midslope zone, with Pleistocene and Holocene combined into "pre-contact" time bin. 